first appeared in 1932. In all, Céline wrote nine novels, a play, a biography of Dr. Semmelweiss, and three virulent pamphlets (two of them anti-Semitic). His anti-Semitism, his rather vague collaboration with German occupation forces and the Vichy government-in-exile, and his post-war incarceration in a Danish prison combined with a difficult and hostile and intransigent personality to cloud his post-war reputation in France though he continued to write and publish both before and after his return to France. At present, five of his novels are available in English translations, three of them in excellent versions by Ralph Manheim. Interest in his work has doubtless been spurred by the current vogue in outrageous or farcical fiction, but, however uneven his production, Céline's major novels will probably survive as 20 th Century classics. Certainly, he merits closer critical scrutiny than he has thus far received.

The following texts, presented here for the first time in translation, deal with virtually the same subject matter but from opposite points in Céline's creative life. The first contains the sketchy and impressionistic jottings of a young recruit, taken in a notebook left with a comrade when Destouches-Céline was evacuated to a hospital early in WW I. These pencil notes, transcribed by B. Gobled and first printed in a special number of Les Cahiers de L'Herne (No. 5, Paris, 1965), were never intended for publication. Indeed, Céline did not turn to literature until the 30 's. The second text, an extract from a fragmentary manuscript dealing with Céline's experience as a young recruit, was destined to form the sequel to his second novel, Death on the Installment Plan. Since Céline was a careful writer, a reviser, and there is no evidence that Casse Pipe was ever completed, we may assume that the fragment would not have been publishd in its present form. Nevertheless, it represents a good sample of the later manner and stands in sharp contrast to the youthful journal which could have served as a rough draft had the notebook been in the author's hands when he was writing his novel. Self-pity and adolsecent aspiration have been replaced by irreverence and self-mockery. The life of the young recruit is here viewed from the other side of the looking-glass by an experienced writer. It is distress reprojected from turmoil.

D. $\mathrm{H}$.

\title{
The Notebook of Cavalryman Destouches
}

1) I don't know how to say what makes me write down my thoughts.

2) To whomever will read these pages.

3) This dismal November evening takes me back thirteen months to the time of my arrival at Rambouillet far from suspecting what awaited me during my charming stay here. Have I then changed so much in one year, I think so ... 5) ... For barracks life instead of plunging me into a [?] (rage . . . sadness induced a state ... like languor) a state from which I emerged with my spirit 
stuffed with resolutions, unfulfillable resolutions, alas, with the result that today 7) entirely formed by this sad life we lead here I am marked by a melancholy within which I maneuver like a bird in the air or a fish in water

I have never in any other field of study so effectively demonstrated my ability to learn.

9) These notes, which as anyone can see are of a diaphanous pallor, are entirely personal and my only purpose is to record a period (complete now perhaps) the first really painful period I have experienced, but perhaps not the 11) last. I write these pages haphazardly. They will be formed and marked by moods which will vary with the day or hour for since my enlistment I have experienced abrupt shifts in my health and morale.

13) October 3-Arrived-Camp full of ponderous, tough-looking non-coms. Snotty corporals. Assigned to a troop the 4th Lt Le Moyne nice kid, Coujon [?] mean bastard slippery as an eel-

15) Baron de Lagrange [?] (a good and sincere officer but a bit unbalanced a nervous type who's subject to attacks I think we can trace back to youthful overindulgence).

17) Surrounded by this motley crew of superiors I take my first steps in military life. Mustn't forget Serat a demoted corporal ... a liar and a tough, who combines loud-mouthed southern affrontery

19) slyness with a curious egotism. Nothing you do for him is enough and how often have I added to my own particular woes his miseries or those I have imagined for him or made up so that he could be spared.

21) From the debts and thefts which I preferred to overlook mixed in with all that a deep nostalgia for freedom, a state of mind that does not make it any easier to take military training.

23) All those horrible awakenings [anguish] [that] to the false gay sound of the bugle begin to symbolize the rancors and the anguish of the raw recruit's daily existence.

25) Going down to the stables in the morning fog. The languid progress of the clogdragging stable detail down the stairs in the halflight. A noble profession the profession of arms. Perhaps the most genuine sacrifices are made

27) by those manipulating manure in the meagre glow of a filthy lantern . . . During brigade training suffering the contempt of

29) a gung ho young officer exposed to the sarcastic comments of a brutish noncom subject to an innate fear of horses I soon lost my enthusiasm and began to give serious consideration to desertion as the only possible way out of the cavalry

31) How often have I returned after grooming the horses and alone on my bed, caught up in an immense despair, cried like a first communicant despite my seventeen years. At those times I felt that I was

33) empty that my energy was phoney and that deep down in me there was nothing that I was not $a$ man I had too long believed in my manhood perhaps many like me do so prematurely perhaps many

35) still believe it though they are older than I and in my situation would also 
feel their hearts drifting like a bottle in the sea tossing about in the insulting waves

37) and the belief that it will never be over while in truth I have suffered as much from the evils of my present situation as from a lack of virility and the awareness of that lack. I have felt that the splendid sermons I delivered a month 39) earlier on the subject of youthful energy were no more than bravado and that at bottom I was no more than a poor misplaced fellow half-demented and using what remained of his faculties

41) to register the total absence of such energy. It is at this point after having reached my spiritual nadir that I can indulge in self-scrutiny in the sort of soulsearching one can do

43) profoundly only when one's soul has joined in the combat. Similarly in catastrophes we see the best sort of men trample women under foot behaving as vilely

45) as the lowest vagrant. In like manner I saw my soul suddenly divest itself of its illusions, of the stoicism with which my assurance had covered it so as to avoid battle with that sad reality for which I . . **

47) What in the world is more melancholy than a December afternoon a Sunday in the barracks?

And yet that sadness which plunges me into the deepest depression

49) I hate to lose it and I feel that only at such times when my soul has softened can I see myself as I am. Am I being poetic no! I don't think so but

51) a fundamental sadness underlies my nature and I lack the courage to banish it by indulging in some pastime or other it soon swells to enormous size

53) to the point that this deep melancholy soon englobes all my troubles and melds with them to torture me in the deeps of my being.

55) I have so complicated and sensitive a nature that the least bit of tactlessness or indelicacy offends me and causes suffering for deep inside

57) I conceal a fundamental pride that frightens even me I wish to dominate no not through artificial power like that of the military but I hope that

59) later or as soon as possible I'll be a complete man, would I ever be one, would I have the luck I need to have that freedom of action that permits one to educate oneself. I want to achieve on my own

61) a place in life that will permit me to indulge all my fancies (Alas) would I be forever free and alone having as I believe too complex a spirit

63 ) to find a companion whom I could love for very long. I don't know. But what I want above all else is to live

65) a life filled with events which I hope providence will place in my path so that I won't end up like so many having blindly followed a single track

67) achieving a formless continuity on an earth and in a life which lack those detours that permit one to accomplish his moral education

69) if I survive the great crises life may hold for me perhaps I shall be less

*This sentence is an approximation of a passage Mr. Gobled finds particularly illegible. 
unhappy than some for I want to know and understand

70) to put it simply I am proud is that a weakness I don't believe it is and it will surely bring misery or perhaps Success.

\section{Louis-Ferdinand Céline}

tr. David Hayman

\section{from Casse-Pipe}

Corporal Le Meheu occupied the far end of the guardhouse, his elbows on the table, by the lampshade. He was snoring. Far off as I was, I saw the night light glinting on his little mustache. His eyes were hidden by his helmet. Its weight made his head nod . . . He kept rising up ... He was struggling against sleep ... It had just struck the hour... .

I'd been waiting in front of the gate for a long time. Some gate, a gate that gave you notions, one of those real cast-iron giants, a monster trellis of spears, upright like that, in the pitch black.

My orders I held in my hand ... The hour was there, written down.

The sentry from the box had pushed open the wicket himself, with his rifle butt. He had just called in:

"Corporall Here's the volunteer!"

"Get him in here, the dumb prick!"

There were a good twenty men flopped on the straw of the stall. They shook themselves. They grunted. The sentry barely had the tips of his ears sticking out over the heap of capes he had on ... such a pile of them he looked like a cloud colored artichoke . . . they bunched up on the paved floor at his feet, a petticoat with flares. I'd noticed the paving stones already, bigger than skulls ... almost step in between them ...

We went into this den, which stank so bad from the men it made you weak; the stink got deep in your nose, enough to knock you out . . . It got you sniffing all over the place, it was so unbelievably strong, biting . . . Meat, piss, and chewing tobacco and bladder reek, they had an overpowering stink, and then the sad cold coffee, and then a taste of horseshit, and then something bland, like the smell of a dead rat, hovering in the corners . . . It worked on your lungs, you had to force every breath. But that guy crouched by the lamp, he didn't give me any time to think about it.

"Listen, lead ass, you need my boots to get you started? . . . Holler out your name, what's the word on you? . . . You think you can sign up without me? Want me to send a wheel barrow for you ..."

Certainly I wanted to get to the table, but everybody's feet were sticking out in the way . . . all these spurred boots . . . steaming . . . all the flopouts in the straw. They snored away all jammed together . . . Bundled up in their rotten clothes, they made a solid barrier. I stepped over the whole pile, as best I could. The corporal had shamed me. 